\title{
PEMANFAATAN LIMBAH CANGKANG KERANG DARA (ANADARA GRANOSA) SEBAGAI BAHAN TAMBAH DAN KOMPLEMEN TERHADAP KUAT TEKAN BETON NORMAL
}

\author{
Restu Andika ${ }^{1)}$, Hendramawat Aski Safarizki²) \\ 1) Fakultas Teknik, Program Studi Teknik Sipil, Universitas Veteran Bangun Nusantara, \\ Sukoharjo, Jl. Letjen Sudjono Humardhani, No.1, Jombor, Sukoharjo; Telp. 0271-593156. \\ Email : restuira59@gmail.com \\ ${ }^{2)}$ Fakultas Teknik, Program Studi Teknik Sipil, Universitas Veteran Bangun Nusantara, \\ Sukoharjo, Jl. Letjen Sudjono Humardhani, No.1, Jombor, Sukoharjo; Telp. 0271-593156. \\ Email : hendra.mawat@gmail.com
}

\begin{abstract}
ABSTRAK
Beton adalah bahan konstruksi yang banyak digunakan pada pembangunan pada saat ini. Beton didapat dari pencampuran agregat halus dan agregat kasar. Bahan penyusun beton berupa pasir, kerikil, dengan menambahkan secukupnya bahan perekat berupa semen dan air sebagai bahan pembantu guna keperluan reaksi kimia selama proses pengerasan dan perawatan beton. Pada penelitin ini beton dibuat dengan bahan tambah dan komplemen serbuk cangkang kerang darah. Proses perawatan dengan ditumbuk terlebih dahulu sehingga menghasilkan serbuk sebagai bahan tambah dan komplemen dengan presentase 5\%:7,5\% terhadap kuat tekan beton $20 \mathrm{MPa}$ dalam waktu pengujian 1, 7, 28 hari menggunakan metode SNI. Hasil pengujian beton normal sebesar 22 Mpa pada 28 hari. Beton bahan tambah serta komplemen diuji pada umur 1, 3, 28 hari. Mengalami peningkatan sebesar $7 \mathrm{MPa}$ pada campuran bahan tambah 5\% dan peningkatan $3 \mathrm{MPa}$ pada bahan tambah 7,5\% serta mengalami penurunan pada komplemen sebesar $7 \mathrm{MPa}$.
\end{abstract}

Kata kunci: bahan tambah, beton, kerang darah, komplemen

\begin{abstract}
Concrete is a construction material that is widely used in construction at this time. Concrete is obtained from mixing fine aggregate and coarse aggregate. Concrete constituents in the form of sand, gravel, by adding enough adhesive in the form of cement and water as an auxiliary material for chemical reaction during the hardening and maintenance of the concrete. In this research concrete is made with added ingredients and blood shell shell powder complement. The treatment process is crushed in advance so as to produce powder as an added ingredient and complement with a percentage of 5\%: $7.5 \%$ to the compressive strength of $20 \mathrm{MPa}$ concrete during testing time 1, 7, 28 days using the SNI method. The normal concrete test results were $22 \mathrm{MPa}$ at 28 days. Concrete added ingredients and complements were tested at 1, 3, 28 days. Experienced an increase of $7 \mathrm{MPa}$ in the $5 \%$ added ingredients mixture and a $3 \mathrm{MPa}$ increase in $7.5 \%$ added ingredients and decreased in the complement of $7 \mathrm{MPa}$.
\end{abstract}

Keywords: added ingredients, concrete, blood shells, complement

\section{PENDAHULUAN}

Beton merupakan suatu bahan konstruksi yang banyak digunakan pada pembangunan sekarang ini. Beton didapat dari pencampuran bahan-bahan agregat halus dan kasar yaitu pasir, kerikil, dengan menambahkan secukupnya bahan perekat semen dan air sebagai bahan pembantu guna keperluan reaksi kimia selama proses pengerasan dan perawatan beton secara langsung. Nilai kekuatan serta daya tahan (durability) beton merupakan fungsi dari banyak faktor, diantaranya ialah nilai perbandingan campuran, mutu bahan penyusun, metode pengecoran, pelaksanaan, temperatur, dan kondisi perawatan.

Pada penelitian (Permana, 2014) sebelumnya yang melakukan penelitian Cangkang Kerang Darah sebagai substitusi agrgegat halus menerangkan bahwa, Kerang adalah hewan air yang termasuk hewan bertubuh lunak (moluska). Semua kerang-kerangan memiliki sepasang cangkang (disebut juga cangkok atau katup) yang biasanya simetri cermin yang terhubung dengan suatu ligamen (jaringan 
ikat). Pada kebanyakan kerang terdapat dua otot aduktor yang mengatur buka - tutupnya cangkang. Pada pengujian ini menggunakan jenis kerang Anadara granosa (Kerang Darah)

Kerang Darah (Anadara granosa) merupakan salah satu kerang yang banyak terdapat di perairan Indonesia dan banyak dikonsumsi oleh masyarakat karena kandungan protein yang tinggi. Menurut (Kementerian Kelautan dan Perikanan, 2011) nilai produksi kerang darah (Anadara granosa) di Indonesia pada tahun 2011 yaitu 373,202 ton dan bila dibandingkan tahun sebelumnya mengalami peningkatan $44,12 \%$. Kulit kerang merupakan bagian dari kerang yang tidak bisa di konsumsi, sehingga hanya dibiarkan menumpuk menjadi limbah rumah tangga.

Produksi limbah cangkang kerang di area Sukoharjo pada tahun 2019 ini ditafsir sekitar $360 \mathrm{~kg}$ per hari. Rata-rata ini didapat dari pengambilan data secara acak pada tempat yang memproduksi makanan kerang darah. Melihat produksi limbah cangkang kerang dara di sekitar Sukoharjo cukup banyak dan tidak dimanfaatkan. Sehingga, hal inilah yang mendorong penulismemanfaatkan limbah cangkang kerang sebagai bahan tambah dan komplemen untuk membuat beton yang kuat dan ekonomis.

Pada umunya beton sering digunakan sebagai struktur dalam konstruksi suatu bangunan. Dalam teknik sipil, beton digunakan untuk bangunan pondasi, kolom, balok dan plat lantai, dll. Menurut Mulyono (2005) terdapat beberapa jenis beton yang dipakai dalam konstruksi suatu bangunan yaitu sebagai berikut ini :

1) Beton normal adalah beton yang menggunakan agregat normal.

2) Beton bertulang adalah beton yang menggunakan tulangan dengan jumlah dan luas tulangan tanpa pratekan dan direncanakan berdasarkan asumsi bahwa kedua material bekerja secara bersamasama dalam menahan gaya yang bekerja

3) Beton pracetak adalah beton yang elemen betonnya tanpa atau dengan tulangan yang dicetak di tempat yang berbeda dari posisi akhir elemen dalam strukur

4) Beton pratekan adalah beton dimana telah diberikan tegangan dalam bentuk mengurangi tegangan tarik potensial dalam beton akibat pemberian beban yang bekerja.

5) Beton ringan adalah beton yang memakai agregat ringan atau campuran antara agregat kasar ringan dan pasir alami sebagai pengganti ageragat halus ringan dengan ketentuan tidak boleh melampaui berat isi maksimum beton $1850 \mathrm{~kg} / \mathrm{m}^{3}$ harus memenuhi ketentuan kuat tekan dan kuat tarik beton ringan untuk tujuan struktural.

Jenis kerang yang sering dikonsumsi dan dijumpai di Indonesia antara lain sebagai berikut ini :

1) Kerang Darah (Anadara Granosa)

2) Kerang Hijau (Perna Viridis)

3) Kerang Bambu (Ensis leei)

4) Kerang Tiram

5) Kerang Bulu (Anadara Antiquata)

6) Kerang Simping (Pectinidae)

Kerang darah (Anadara granosa) adalah sejenis kerang yang biasa dimakan oleh warga Asia Timur dan Asia Tenggara. Anggota suku Arcidae menyebut kerang darah karena kerang ini menghasilkan hemoglobin berupa cairan merah (www.wikipedia. com).

Kerang ini menghuni kawasan Indo-Pasifik dan tersebar dari pantai Afrika timur sampai ke Polinesia. Hewan ini gemar memendam dirinya ke dalam pasir atau lumpur. Ukuran dewasanya sekitar 5 sampai $6 \mathrm{~cm}$ pada ukuran panjangnya dan 4 sampai $5 \mathrm{~cm}$ pada ukuran lebarnya. Budidaya kerang darah sudah dilakukan karena memiliki nilai ekonomi yang baik. Meskipun biasanya direbus atau dikukus, kerang ini dapat pula digoreng atau dijadikan sate dan makanan kering lainnya.

Dari penjelasan umum di atas cangkang kerang darah mengandung kapur, silikat dan alumina. Adapun komposisi senyawa yang terkandung dalam cangkang kerang dapat dilihat pada Tabel 1 .

Tabel 1 Unsur senyawa kerang darah (Anadara Granosa)

\begin{tabular}{cc}
\hline Komponen & $\begin{array}{c}\text { Cangkang kerang (kadar \% } \\
\text { berat) }\end{array}$ \\
\hline $\mathbf{C a O}$ & 67,072 \\
$\mathrm{SiO}_{2}$ & 8,252 \\
$\mathrm{Fe}_{2} \mathbf{O}_{3}$ & 0,402 \\
$\mathrm{MgO}_{\mathrm{AL}_{2} \mathrm{O}_{3}}$ & 22,652 \\
\hline
\end{tabular}


Supriani (2011) melakukan penelitian dengan mencampur abu cangkang kerang ke dalam campuran beton, didapatkan hasil dengan presentase abu cangkang kerang 5\%, 10\%, dan 15\% Abu cangkang lokan kemungkinan dapat menjadi bahan tambah untuk mempercepat ikatan umur awal beton (Acceleratingadmixture).

Annur (2013) melakukan studi tentang penggunaan cangkang kerang laut sebagai bahan penambah agregat kasar pada campuran beton, didapatkan hasil bahwa dengan presentase cangkang kerang 0\%, 17\%, 31\%, $44 \%$, dan $55 \%$ dari berat agregat kasar dengan FAS 0.42 , dapat menurunkan sifat mekanis beton. Subtitusi abu kulit kerang dengan presentase kulit kerang 0\%, 5\%, 10\%, 15\%, dan $20 \%$ ditinjau dari kuat tekan, kuat tarik belah, absorpsi, dan makrostruktur didapatkan adanya kenaikan pada nilai slump, penurunan nilai kuat tekan dan kuat tarik belah (Rezeki, 2013).

Permana (2014) melakukan pengujian tentang pengaruh penambahan tumbukan kulit kerang jenis Anadara granosa sebagai Agregat Halus Terhadap Kuat Tekan Beton K-225, menyatakan dengan presentase kulit kerang $0 \%, 2,5 \%, 5 \%, 7,5 \%$, dan $10 \%$ ditinjau dari waktu perawatan 7 hari, 14 hari dan 28 hari menggunakan metode SNI dan JIS.

Pada penelitin ini beton dibuat dengan bahan tambah dan komplemen serbuk cangkang kerang darah. Proses perawatan dengan ditumbuk terlebih dahulu sehingga menghasilkan serbuk sebagai bahan tambah dan komplemen dengan presentase 5\% dan $7,5 \%$ terhadap kuat tekan beton $20 \mathrm{MPa}$ dalam waktu pengujian 1, 7, 28 hari menggunakan metode SNI.

\section{METODE}

\section{Bahan dan Alat}

Macam-macam peralatan yang digunakan antara lain adalah sebagai berikut:

1) Concrete Compression Machine

2) Ayakan

3) Timbangan/Neraca

4) Gelas Ukur

5) $\mathrm{Mol} /$ Cetakan Beton

6) Mesin Molen (Concrete Mixer)

7) Alat Uji Slump (Concrete Slump Test)

8) Cetok

9) Loyang
10) Kuas

11) Penggaris

Macam-macam bahan yang digunakan antara lain adalah sebagai berikut :

1) Semen

2) Agregat Kasar

3) Agregat Halus

4) Air

5) Serbuk Cangkang Kerang Darah

6) Oli

\section{Metode penelitian}

Penelitian ini melalui beberapa tahapan yang harus sesuai dan dapat dijabarkan seperti di berikut ini.

\section{Tahap Persiapan Bahan Material}

Proses mempersiapkan bahan material yang akan digunakan untuk pembuatan benda uji seperti agregat halus, agregat kasar, semen portland dan bahan tambah.

\section{Tahap Pengujian Material}

Tahapan pengujian material yang harus dilakukan sesuai yang disyaratkan pada SNI yang digunakan seperti pengujian gradasi, kandungan lumpur dan berat jenis.

\section{Tahap Pembuatan Benda Uji}

Proses pembuatan benda uji dengan campuran yang sudah dihitung dan benda uji pada penelitian ini berbentuk silinder dengan diameter $15 \mathrm{~cm}$ dan tinggi $30 \mathrm{~cm}$.

\section{Tahap Perawatan Benda Uji}

Proses perawatan benda uji dilakukan dengan cara merendam benda uji dengan durasi waktu sesuai yang telah ditentukan dan memiliki tujuan supaya benda uji kering secara sempurna.

\section{Tahap Pengujian}

Pengujian dilakukan dengan alat yang disebut Compression Testing Machine (CTM) untuk mengetahui kuat tekan yang direncanakan apakah sesuai atau tidak.

\section{Tahap Analisa Hasil}

Setelah benda uji lolos dari tahap pengujian dan mencapai kuat tekan yang direncanakan maka tahapan selanjutnya adalah pembuatan analisa hasil guna mengetahui faktor yang dapat mempengaruhi benda uji tersebut. 
Tahapan penelitian secara lengkap seperti tampak pada bagan alir penelitian pada Gambar 1.

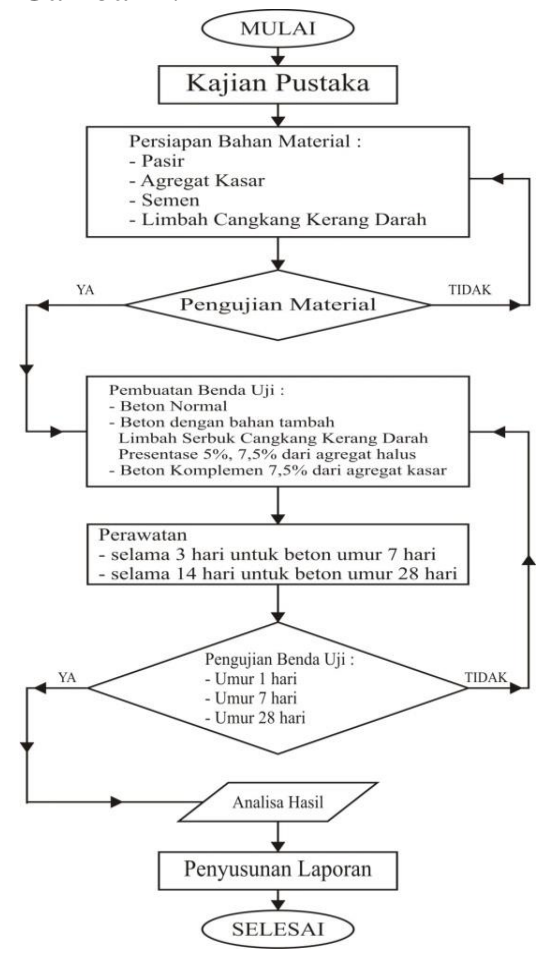

Gambar 1 Bagan Alir Penelitian

\section{HASIL DAN PEMBAHASAN}

\section{Pengujian Agregat}

Pengujian agregat meliputi pengujian berat jenis, pengujian gradasi, pengujian kandungan lumpur. Data pengujian dapat di lihat pada Tabel 2.

Pengujian Bahan Tambah (serbuk limbah cangkang kerang darah) dilakukan melalui beberapa tahapan. Antara lain :

- Proses Pembersihan Bahan Tambah

- Proses Membuat Serbuk Cangkang Kerang

- Proses Pemisahan Ukuran Gradasi
Tabel 2 Pengujian Agregat

\begin{tabular}{ccccc}
\hline No & $\begin{array}{c}\text { Jenis } \\
\text { Agregat }\end{array}$ & $\begin{array}{c}\text { Gradas } \\
\mathbf{i} \\
\text { Agrega } \\
\mathbf{t}\end{array}$ & $\begin{array}{c}\text { Berat } \\
\text { Jenis } \\
\text { SSD }\end{array}$ & $\begin{array}{c}\text { Kandunga } \\
\text { n lumpur }\end{array}$ \\
\hline $\mathbf{1}$ & $\begin{array}{c}\text { Agregat } \\
\text { Halus }\end{array}$ & Zona 2 & 2,59 & $0,5 \%$ \\
$\mathbf{2}$ & $\begin{array}{c}\text { Agregat } \\
\text { Kasar }\end{array}$ & Zona 3 & 2,67 & $0,7 \%$ \\
& & & \\
\hline
\end{tabular}

Tahapan yang terakhir pengujian berat jenis bahan tambah dan diperoleh hasil seperti pada Tabel 3 .

Tabel 3 Berat Jenis Bahan Tambah

\begin{tabular}{ccc}
\hline No & Keterangan & Hasil \\
\hline $\mathbf{1}$ & Berat Jenis Curah & 2,33 \\
& Kering ( Sd ) & \\
$\mathbf{2}$ & Berat Jenis Curah & 2,48 \\
& Jenuh ( SSD ) & 2,75 \\
$\mathbf{3}$ & Berat Jenis Semu & $6,5 \%$ \\
$\mathbf{4}$ & Penyerapan Air & \\
\hline
\end{tabular}

Hasil

Hasil Pengujian Nilai Slump seperti pada Tabel 4 Berikut ini.

Tabel 4 Hasil Uji Slump

\begin{tabular}{ccc}
\hline No & Variasi Beton & Nilai Slump (cm) \\
\hline $\mathbf{1}$ & Beton Normal & 2,6 \\
$\mathbf{2}$ & Beton Tambah 5\% & 1,5 \\
$\mathbf{3}$ & Beton Tambah & 1 \\
& $7,5 \%$ & 0,8 \\
$\mathbf{4}$ & Beton Komplemen & \\
& BT 7,5\%
\end{tabular}

Dilaukan pengujian kuat tekan beton umur 1 hari, 7 hari dan 28 hari dengan menggunakan alat Concrete Compression Machine untuk menguji kuat tekan. Hasil pengujian seperti tampak pada tabel 5, tabel 6, dan tabel 7 .

Tabel 5 Hasil Kuat Tekan 1 Hari

\begin{tabular}{cccccc}
\hline No & Presentase Serbuk Kerang & $\begin{array}{c}\text { Berat Beton Silinder } \\
(\mathrm{Kg})\end{array}$ & $\begin{array}{c}\text { Kuat Tekan } \\
(\mathrm{MPa})\end{array}$ & $\begin{array}{c}\text { Rata-rata } \\
(\mathrm{MPa})\end{array}$ & $\begin{array}{c}\text { Rata-rata + } \\
\text { Deviasi }\end{array}$ \\
\hline $\mathbf{1}$ & $0 \%$ & 12,9 & 5,27 & 5,25 & 5,28 \\
& & 12,8 & 5,23 & & \\
$\mathbf{2}$ & $5 \%$ & 13,1 & 7,36 & 6,82 & 7,58 \\
& & 13 & 6,28 & & \\
$\mathbf{3}$ & $7,5 \%$ & 13,1 & 6,96 & 7,13 & 7,37 \\
& & 13,2 & 7,30 & & \\
$\mathbf{4}$ & Komplemen & 13,2 & 8,27 & 7,13 & 8,74 \\
& & 13,1 & 6,00 & & \\
\hline
\end{tabular}


Tabel 6 Hasil Kuat Tekan 7 Hari

\begin{tabular}{cccccc}
\hline No & Presentase Serbuk Kerang & $\begin{array}{c}\text { Berat Beton Silinder } \\
(\mathrm{Kg})\end{array}$ & $\begin{array}{c}\text { Kuat Tekan } \\
(\mathrm{MPa})\end{array}$ & $\begin{array}{c}\text { Rata-rata } \\
(\mathrm{MPa})\end{array}$ & $\begin{array}{c}\text { Rata-rata + } \\
\text { Deviasi }\end{array}$ \\
\hline $\mathbf{1}$ & $0 \%$ & 12,9 & 14,9 & 14,8 & 14,9 \\
$\mathbf{2}$ & $5 \%$ & 12,8 & 14,7 & & \\
& & 12,9 & 19,5 & 19,2 & 19,6 \\
$\mathbf{3}$ & $7,5 \%$ & 13 & 18,9 & & \\
& & 13,05 & 14,6 & 15,5 & 16,7 \\
$\mathbf{4}$ & Komplemen & 13,1 & 16,4 & & \\
& & 13,1 & 8,8 & 8,52 & 8,88 \\
\hline
\end{tabular}

Tabel 7 Hasil Kuat Tekan 28 Hari

\begin{tabular}{cccccc}
\hline No & Presentase Serbuk Kerang & $\begin{array}{c}\text { Berat Beton Silinder } \\
(\mathrm{Kg})\end{array}$ & $\begin{array}{c}\text { Kuat Tekan } \\
(\mathrm{MPa})\end{array}$ & $\begin{array}{c}\text { Rata-rata } \\
(\mathrm{Mpa})\end{array}$ & $\begin{array}{c}\text { Rata-rata + } \\
\text { Deviasi }\end{array}$ \\
\hline $\mathbf{1}$ & $0 \%$ & 12,9 & 22,8 & 22,7 & 22,9 \\
& & 12,8 & 22,7 & & \\
$\mathbf{2}$ & $5 \%$ & 13 & 30,4 & 29,1 & 30,9 \\
& & 13,2 & 27,8 & & \\
$\mathbf{3}$ & $7,5 \%$ & 13 & 24,1 & 23,9 & 24,2 \\
& & 12,9 & 23,8 & & 16,3 \\
$\mathbf{4}$ & Komplemen & 13 & 16,1 & 15,6 & 16,3 \\
& & 12,9 & 15,2 & & \\
\hline
\end{tabular}

Dari hasil pengujian kuat tekan beton menghasilkan grafik seperti pada gambar 2 . Berdasarkan grafik pada Gambar 2 dapat disimpulkan bahwa kenaikan kuat tekan beton dari beton normal terjadi pada presentase penambahan serbuk cangkang kerang darah di $5 \%$ dan $7,5 \%$, namun terjadi penurunan kuat tekan beton dari beton normal pada komplemen beton sebesar 7 Mpa dari beton normal.

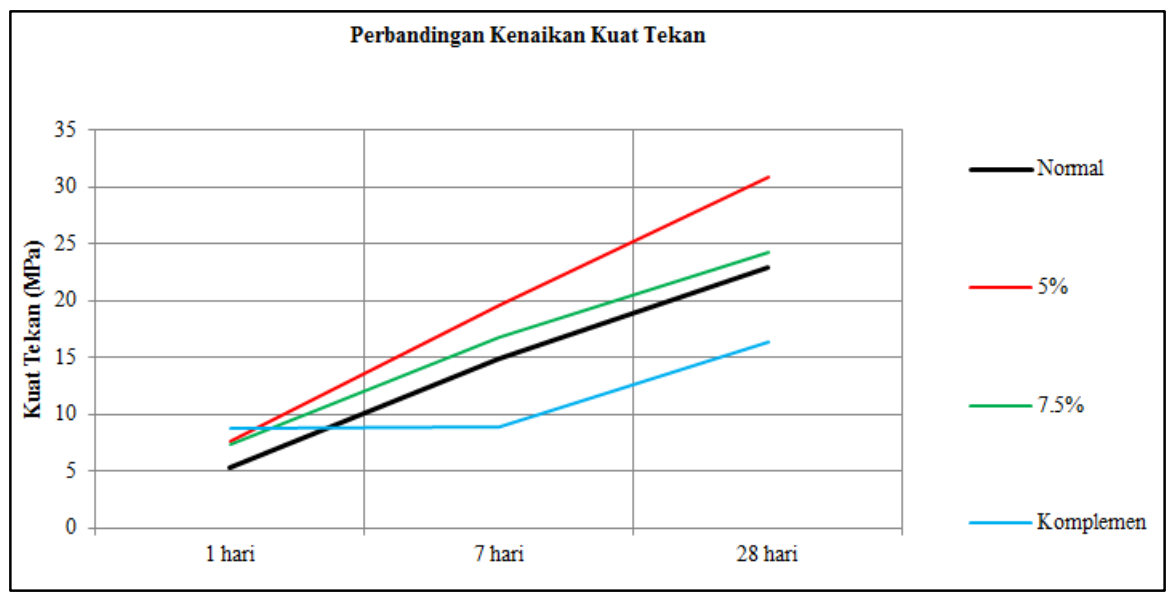

Gambar 2 Perbandingan Kuat Tekan

Penurunan dan kenaikan pada beton dengan bahan tambah serbuk kerang darah dan komplemen terjadi akibat reaksi dari kandungan yang terdapat pada serbuk cangkang kerang darah yaitu Cao (Kalsium Oksida) sebesar 67,07\% dan $\mathrm{MgO}$ (Magnesium Oksida) sebesar 22,65\%.

Senyawa $\mathrm{CaO}$ (Kalsium Oksida) sebesar $67,07 \%$ pada cangkang kerang darah menghasilkan energi panas sehingga penggunaan bahan tambah dan komplemen serbuk cangkang kerang darah dengan presentase yang sesuai dapat meningkatkan kuat tekan beton. Namun, penggunaan yang berlebih menyebabkan beton hidrasi dan mudah getas sehingga menurunkan kuat tekan beton. 
Senyawa $\mathrm{MgO}$ (Magnesium Oksida) sebesar $22,65 \%$ pada cangkang kerang darah memiliki sifat mudah mengembang apabila dicampur dengan air. Sehingga, penggunaan serbuk cangkang kerang darah yang berlebih dapat menyebabkan beton mengembang dan mudah pecah (Expansi). Dari senyawa yang terdapat pada cangkang kerang darah maka dapat menaikkan kuat tekan apabila presentase campuran serbuk cangkang kerang tidak berlebih dan dapat menurunkan kuat tekan apabila campuran serbuk cangkang kerang berlebih.

\section{KESIMPULAN}

Pengaruh serbuk limbah cangkang kerang darah dapat meningkatkan kuat tekan beton dengan bahan tambah dan dapat menurunkan kuat tekan beton komplemen.

Penambahan serbuk limbah cangkang kerang darah dapat meningkatkan kuat tekan $20 \mathrm{MPa}$ apabila penambahan maksimal $7,5 \%$ dari presentase agregat halus. Kenaikan kuat tekan beton dikarenakan senyawa $\mathrm{CaO}$ (Kalsium Oksida) sebesar $67,07 \%$ yang memiliki sifat rekat apabila dicampur air pada campuran beton.

Pada presentase 5\% sebagai bahan tambah dari agregat halus meningkatkan kuat tekan beton sebesar $10 \mathrm{Mpa}$, pada presentase 7,5\% kenaikan beton sebesar 2 Mpa. Dan, mengalami penurunan pada presentase 7,5\% sebagai komplemen dari agregat kasar sebesar $-7 \mathrm{Mpa}$

\section{DAFTAR PUSTAKA}

Rezeki, Ade Sri, 2013, Pengaruh Subtitusi Abu Kulit Kerang Terhadap Sifat Mekanik Beton, Tugas Akhir Program Studi Teknik Sipil Universitas Sumatera Utara, Medan.

Anonim, 1989, SK SNI S04- 1989, (Spesifikasi Bahan Bangunan Bagian A, Departemen Pekerjaan Umum, Jakarta.

Anonim, 1992, SNI 03-2834-1992, (Tata Cara Pembuatan Rencana Campuran Beton Normal), Badan Standarisasi Nasional, Jakarta.

Anonim, 2013, SNI 2847:2013, (Persyaratan Beton Struktural Untuk Bangunan Gedung), Badan Standarisasi Nasional, Jakarta.

Permana, Dede Indah., dkk, 2014, Pengaruh Penambahan Tumbukan Kulit Kerang Jenis Anadara Granosa Sebagai Agregat Halus Terhadap Kuat Tekan Beton K-225, Tugas Akhir Program Studi Teknik Sipil Universitas Islam 45, Bekasi.

Supriani, Fepy, 2011, Pengaruh Penambahan Abu Cangkang Lokan Terhadap Kuat Tekan Beton, Program Studi Teknik Sipil Universitas Sumatera Utara, Medan.

Hatta Annur, 2013, Studi Penggunaan Cangkang Kerang Laut Sebagai Bahan Penambah Agregat Kasar Pada Campuran Beton, Jurusan Teknik Sipil, Fakultas Teknik Universitas Khairun, Ternate.

Mulyono, Tri, 2005, Teknologi Beton, Yogyakarta.

Wikipedia Ensikopedia, 2019, https://id.m.wikipedia.org/wiki/Kerang_darah, Diakses Pada 27 Maret 2019. 